\title{
GLOBÁLIS KLÍMAMODELLEK VALIDÁCIÓJA AZ ÉSZAKI FÉLGÖMBRE TÁVKAPCSOLATI RENDSZEREK FELHASZNÁLÁSÁVAL
}

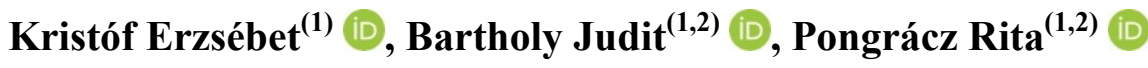 \\ ${ }^{(1)}$ ELTE Meteorológiai Tanszék, 1117 Budapest, Pázmány Péter sétány 1/A \\ ${ }^{(2)}$ ELTE TTK, Kiválósági Tudásközpont, 2462 Martonvásár, Brunszvik u. 2. \\ e-mail: ekristof86@caesar.elte.hu, bartholy@caesar.elte.hu,prita@nimbus.elte.hu
}

\section{Bevezetés}

A XX. század során számos nagyskálájú távkapcsolati rendszert (más néven oszcillációs jelenséget) azonosítottak, amelyek befolyással bírhatnak Földünk éghajlatára. Ezek a távkapcsolatok olyan nagytérségü folyamatok, amelyek egymástól távol eső területek légköri vagy óceáni állapot-határozóinak ellentétes előjelủ együttváltozásaként (azaz antikorrelációjaként) értelmezhetők. A legintenzívebb területeket akciócentrumaik meghatározásával azonosíthatjuk. Az Észak-csendes-óceáni Oszcillációt ${ }^{1}$ és az Észak-atlanti Oszcillációt ${ }^{2}$ az átlagos tengerszinti légnyomásmező korrelációanalízise alapján mutatták ki (Walker \& Bliss, 1932). A $700 \mathrm{hPa}$-os légnyomási szint geopotenciális magasságmezőjének elemzése alapján pedig olyan, kettőnél több központú rendszereket azonosítottak, mint a Skandináv Oszcilláció ${ }^{3}$ és az Észak-atlanti/Nyugat-oroszországi Rendszer ${ }^{4}$ (Barnston \& Livezey, 1987). A Kárpát-medence térségéhez közelebb, a Földközi-tenger medencéje feletti akciócentrumokkal bíró Mediterrán Oszcillációt ${ }^{5}$ az $500 \mathrm{hPa}$-os geopotenciális magasságmezőben azonosították (Conte et al., 1989).

A távkapcsolati rendszerek hatása különösen a téli hónapokban lehet jelentős a Kárpátmedencében. Ebben az évszakban a nagytérségü cirkulációs jelenségek dominálnak a kisebb skálájú légköri folyamatok felett, így szerepük meghatározó lehet térségünk hőmérsékleti és csapadékviszonyainak alakításában. Az oszcillációs rendszerek jövőbeli helyzetének és intenzitásának minél pontosabb ismerete tehát kiemelkedő jelentőséggel bír a Kárpát-medencére vonatkozó éghajlati becslések készítése során.

Az éghajlat változása többek között általános cirkulációs modellekkel ${ }^{6}$ szimulálható. A legfejlettebb modellek tér- és időbeli felbontása megfelelő ahhoz, hogy ezek alapján a Kárpát-medence XXI. században várható éghajlatára megállapításokat tegyünk. Célunk a Kapcsolt modelleket összehasonlító projekt 5. fázisa ${ }^{7}$ keretében elérhető GCM-ek XX. század második felére vonatkozó történeti szimulációinak az Európai Középtávú Elörejelző Központ ${ }^{8}$ ERA-20C reanalízis adatbázisával való statisztikai összehasonlítása, azon GCM-ek kiválasztása érdekében, amelyek jövőbeli szimulációinak vizsgálata hozzásegíthet pontosabb éghajlati becslések készítéséhez. Az értékelésünk arra a kérdésre keresi a választ, hogy mely modellek reprodukálják a legpontosabban az északi félgömb légköri oszcillációs jelenségeit, illetve azok hatását a Kárpát-medence térségére. A kutatás első lépéseként az északi félgömb, Kárpát-medencére potenciálisan hatást gyakorló légköri oszcillációs jelenségeit azonosítjuk mind a reanalízis, mind a modellszimulációk adatsorai alapján. Ezt követően a GCM-ek

\footnotetext{
${ }^{1}$ North Pacific Oscillation, NPO

2 North Atlantic Oscillation, NAO

${ }^{3}$ Scandinavian Pattern, SCA

${ }^{4}$ East Atlantic/Western Russia Pattern, EA/WR

${ }^{5}$ Mediterranean Oscillation, MO

${ }^{6}$ general circulation models, GCMs

${ }^{7}$ Coupled Model Intercomparison Project Phase 5, CMIP5

${ }^{8}$ European Centre for Medium-Range Weather Forecasts, ECMWF
} 
összehasonlítandók a reanalízis adatsorok alapján kapott eredményekkel. Végül az azonosított légköri oszcillációk és a Kárpát-medence légköri állapothatározóinak kapcsolata vizsgálandó. A tanulmányban statisztikai vizsgálataink legfontosabb lépéseit foglaljuk össze.

\section{A vizsgált adatsorok}

Az északi félgömb távkapcsolati rendszereinek azonosítása érdekében a GCM-ek légköri modelljeinek többségében 1950-től elérhető napi adatokat vetettük össze az ERA-20C reanalízis adatbázisának napi adatsoraival. Ahhoz, hogy az időbeli változást megfigyelhessük, három 30 éves időszak, 1951-1980, 1961-1990 és 1971-2000 téli hónapjainak (december, január és február) napi adatait elemeztük. A vizsgálatokat az $500 \mathrm{hPa}$-os geopotenciális magassági mezőn hajtottuk végre, ugyanis mind a NAO, mind magasabb szintek távkapcsolati rendszereinek lenyomata kimutatható ezen a szinten.

Az ERA-20C adatbázisban általában három vagy hat órás adatsorok érhetők el, amelyekből napi átlagokat képeztünk, ugyanis a GCM-ek többségénél ez az archiválásra kerülő legfinomabb időbeli felbontású adat. A GCM-ek jelentős része $2,5^{\circ}$-os vagy durvább rácsfelbontású, így statisztikai vizsgálatuk a Kárpát-medence viszonylag kis kiterjedése miatt nem célszerü. Térbeli felbontásként $2^{\circ}$-ot választva, az 1. táblázatban felsorolt GCM-ek szimulációit elemeztük, amelyeket bilineáris interpoláció alkalmazásával interpoláltunk az északi félgömb $46 \times 180$ rácsponttal rendelkező rácsára.

1. táblázat: A vizsgálathoz alkalmazott GCM-ek neve, fejlesztö intézménye és a légköri modell eredeti (interpoláció előtti) rácsfelbontása. A történeti modellszimulációk rli1p1 realizációit használtuk fel a CCSM4 modell kivételével, amelynek r6ilp1 realizációját alkalmaztuk.

\begin{tabular}{|c|c|c|}
\hline $\begin{array}{l}\text { A GCM-ek } \\
\text { neve }\end{array}$ & A GCM-eket fejlesztő intézmény & $\begin{array}{l}\text { Eredeti rácsfelbontás: } \\
\text { szélesség } \times \text { hosszúság }\end{array}$ \\
\hline ACCESS1-0 & $\begin{array}{c}\text { Commonwealth Scientific and Industrial Research Organization } \\
\text { (CSIRO) and Bureau of Meteorology (BOM), Ausztrália }\end{array}$ & $1,25^{\circ} \times 1,875^{\circ}$ \\
\hline ACCESS1-3 & $\begin{array}{l}\text { Commonwealth Scientific and Industrial Research Organization } \\
\text { (CSIRO) and Bureau of Meteorology (BOM), Ausztrália }\end{array}$ & $1,25^{\circ} \times 1,875^{\circ}$ \\
\hline CCSM4 & $\begin{array}{c}\text { National Center for Atmospheric Research (NCAR), } \\
\text { Amerikai Egyesült Államok }\end{array}$ & $\sim 0,9424^{\circ} \times 1,25^{\circ}$ \\
\hline CMCC-CM & $\begin{array}{l}\text { Centro Euro-Mediterraneo per i Cambiamenti (CMCC) } \\
\text { (Euro-Mediterranean Center on Climate Change), Olaszország }\end{array}$ & $\sim 0,74843^{\circ} \times 1^{\circ}$ \\
\hline HadGEM2-AO & $\begin{array}{c}\text { National Institute of Meteorological Research (NIMR), } \\
\text { Dél-Korea }\end{array}$ & $1,25^{\circ} \times 1,875^{\circ}$ \\
\hline HadGEM2-CC & $\begin{array}{l}\text { Met Office Hadley Centre (MOHC), } \\
\text { Egyesült Királyság }\end{array}$ & $1,25^{\circ} \times 1,875^{\circ}$ \\
\hline MIROC5 & $\begin{array}{l}\text { Atmosphere and Ocean Research Institute (AORI), The University of } \\
\text { Tokyo and National Institute for Environmental Studies (NIES), } \\
\text { Agency for Marine-Earth Science and Technology (JAMSTEC), Japán }\end{array}$ & $\sim 1,40076^{\circ} \times 1,40625^{\circ}$ \\
\hline MPI-ESM-LR & Max Planck Institute for Meteorology, Németország & $\sim 1,86526^{\circ} \times 1,875^{\circ}$ \\
\hline MPI-ESM-MR & Max Planck Institute for Meteorology, Németország & $\sim 1,86526^{\circ} \times 1,875^{\circ}$ \\
\hline MPI-ESM-P & Max Planck Institute for Meteorology, Németország & $\sim 1,86526^{\circ} \times 1,875^{\circ}$ \\
\hline MRI-CGCM3 & Meteorological Research Institute, Japán & $\sim 1,12149^{\circ} \times 1,125^{\circ}$ \\
\hline MRI-ESM1 & Meteorological Research Institute, Japán & $\sim 1,12147^{\circ} \times 1,125^{\circ}$ \\
\hline
\end{tabular}


Ahhoz, hogy az összes GCM esetében a reanalízis adatbázissal azonos hosszúságú adatsorokat hasonlíthassunk össze, elhagytuk december és január 31. napját, valamint a szökönapokat. Összesen 8280 rácspontban állt rendelkezésünkre egy-egy 2640 elemü idősor az északi félgömbre vonatkozóan, mindhárom 30 éves időszakra. A számítások elvégzéséhez a $\mathrm{CDO}^{9}$ szoftvert és az R statisztikai programnyelvet alkalmaztuk.

\section{Légköri távkapcsolati rendszerek azonosítása statisztikai módszerekkel}

\section{Korrelációanalízis}

A távkapcsolati rendszereket egymástól távol eső területek antikorrelciójaként értelmeztük, így a rácsponti geopotenciális magasság adatsorok korrelációvizsgálata alapján azonosíthatók. A változók közötti lineáris kapcsolat szorosságát mérő Pearson-korrelációkat követően a monoton kapcsolat szorosságát - azaz nemlineáris hatásokat - is figyelembe vevő Spearmankorrelációk is kiszámításra kerültek a rácsponti idősorok között. Eredményül tehát az összes rácspont összes többi rácsponttal vett korrelációjának négydimenziós tömbjéhez jutottunk. Minden egyes rácspontra meghatároztuk a legerösebb negatív - vagyis abszolút minimális korrelációértéket, ezáltal a legerősebb negatív korrelációkat tartalmazó táblázatot kaptunk. A táblázat alapján akciócentrumokként olyan rácspontpárokat azonosítottunk, amelyek geopotenciális magasság értékei kölcsönösen egyértelmủen a legerősebb szignifikáns negatív korrelációban állnak egymással. Az értékek szignifikanciájáról ún. mezőszignifikancia vizsgálattal döntöttünk (Livezey \& Chen, 1983), amely során a potenciális akciócentrumokként megjelölt rácspontok adatsoraihoz hasonló eloszlású új, véletlen számokat tartalmazó adatsorokat generáltunk. Az új adatsorok és az eredeti mező adatsorai közötti korrelációk kiszámításával megállapítható, hogy -0,2-nél erősebb negatív korrelációk nem tekinthetők véletlenszerünek, vagyis a korrelációk szignifikánsnak 0,99 szignifikancia szinten $(\alpha)$.

2. táblázat: Az észak-atlanti/európai térség felett azonosított rácspontpárok.

\begin{tabular}{|c|c|c|c|c|c|}
\hline Térség & Időszak & $\begin{array}{c}\text { 1. és 2. akciócentrum } \\
\text { Pearson-korreláció } \\
\text { alapján }\end{array}$ & $\begin{array}{c}\text { 1. és 2. akciócentrum } \\
\text { Spearman-korreláció } \\
\text { alapján }\end{array}$ & $\begin{array}{l}\text { Pearson- } \\
\text { korreláció } \\
\text { értéke }\end{array}$ & $\begin{array}{c}\text { Spearman- } \\
\text { korreláció } \\
\text { értéke }\end{array}$ \\
\hline \multirow{3}{*}{$\begin{array}{l}\text { Atlanti- } \\
\text { óceán } \\
\text { észak-keleti } \\
\text { medencéje } \\
\text { felett }\end{array}$} & 1951-1980 & $\begin{array}{l}\text { é. sz. } 22^{\circ} \& \text { ny. h. } 34^{\circ}- \\
\text { é. sz. } 50^{\circ} \& \text { ny. h. } 30^{\circ}\end{array}$ & $\begin{array}{l}\text { é. sz. } 22^{\circ} \& \text { ny. h. } 34^{\circ}- \\
\text { é. sz. } 50^{\circ} \& \text { ny. h. } 30^{\circ}\end{array}$ & $-0,500$ & $-0,506$ \\
\hline & 1961-1990 & $\begin{array}{l}\text { é. sz. } 24^{\circ} \& \text { ny. h. } 34^{\circ}- \\
\text { é. sz. } 52^{\circ} \& \text { ny. h. } 28^{\circ}\end{array}$ & $\begin{array}{l}\text { é. sz. } 24^{\circ} \& \text { ny. h. } 34^{\circ}- \\
\text { é. sz. } 52^{\circ} \& \text { ny. h. } 26^{\circ}\end{array}$ & $-0,497$ & $-0,498$ \\
\hline & 1971-2000 & $\begin{array}{l}\text { é. sz. } 26^{\circ} \& \text { ny. h. } 34^{\circ}- \\
\text { é. sz. } 52^{\circ} \& \text { ny. h. } 22^{\circ}\end{array}$ & $\begin{array}{l}\text { é. sz. } 26^{\circ} \& \text { ny. h. } 34^{\circ}- \\
\text { é. sz. } 52^{\circ} \& \text { ny. h. } 22^{\circ}\end{array}$ & $-0,476$ & $-0,478$ \\
\hline \multirow{3}{*}{$\begin{array}{l}\text { Földközi- } \\
\text { tenger } \\
\text { medencéje } \\
\text { felett }\end{array}$} & 1951-1980 & $\begin{array}{l}\text { é. sz. } 38^{\circ} \& \text { k. h. } 6^{\circ}- \\
\text { é. sz. } 24^{\circ} \& \text { k. h. } 28^{\circ}\end{array}$ & $\begin{array}{l}\text { é. sz. } 38^{\circ} \& \text { k. h. } 6^{\circ}- \\
\text { é. sz. } 24^{\circ} \& \text { k. h. } 28^{\circ}\end{array}$ & $-0,438$ & $-0,435$ \\
\hline & 1961-1990 & $\begin{array}{l}\text { é. sz. } 38^{\circ} \& \text { k. h. } 8^{\circ}- \\
\text { é. sz. } 26^{\circ} \& \text { k. h. } 32^{\circ} \\
\end{array}$ & $\begin{array}{l}\text { é. sz. } 42^{\circ} \& \text { k. h. } 12^{\circ}- \\
\text { é. sz. } 28^{\circ} \& \text { k. h. } 36^{\circ}\end{array}$ & $-0,397$ & $-0,404$ \\
\hline & $1971-2000$ & $\begin{array}{l}\text { é. sz. } 38^{\circ} \& \text { k. h. } 14^{\circ}- \\
\text { é. sz. } 26^{\circ} \& \text { k. h. } 38^{\circ}\end{array}$ & $\begin{array}{l}\text { é. sz. } 38^{\circ} \& \text { k. h. } 12^{\circ}- \\
\text { é. sz. } 24^{\circ} \& \text { k. h. } 34^{\circ}\end{array}$ & $-0,424$ & $-0,425$ \\
\hline
\end{tabular}

Az ERA-20C-re számolt Pearson- és Spearman-korrelációk alapján összesen hat akciócentrumpárt azonosítottunk öt földrajzi térségben: egy-egy párt a Csendes-óceán, ÉszakAmerika, a Földközi-tenger és az Atlanti-óceán északnyugati és északkeleti medencéje felett, illetve két párt Belső-Ázsia felett (Kristóf et al., 2018a). Az Atlanti-óceán északkeleti és a

\footnotetext{
${ }^{9}$ Climate Data Operators
} 
Földközi-tenger medencéje (a továbbiakban: észak-atlanti/európai térség) felett azonosított rácspontpárok az Észak-atlanti Oszcilláció és a Mediterrán Oszcilláció lenyomatának tekinthetők. Földrajzi koordinátáik, valamint korrelációik értéke a 2. táblázatban található.

A három vizsgált időszak alapján a legnagyobb változás az Atlanti-óceán északkeleti medencéje felett található távkapcsolati rendszer esetén figyelhető meg, amelynek északabbi akciócentruma kelet felé tolódott az ezredfordulóhoz közeledve, amelyet korábban Jung \& Hilmer (2000) azonosított. A Pearson- és Spearman-korrelációk alapján meghatározott akciócentrumok helyzete az észak-atlanti/európai térségben nem tér el lényegesen, a legnagyobb különbség $4^{\circ}$, míg a teljes északi félgömböt figyelembe véve $8^{\circ}$. Utóbbi az atlanti-óceán északnyugati medencéje fölött mérhetö.

Az akciócentrumok korrelációanalízissel való azonosítása egyszerünek bizonyult eltolásés szorzásinvarianciája miatt, vagyis a rácspontok közötti korrelációértékek nem változnak attól függően, hogyan súlyozzuk a rácspontokat, illetve a számítás az adatsorok standardizálására sem érzékeny. A módszerrel azonban ok-okozati összefüggések nem deríthetők fel, valamint a rácsponti idősorok közötti kapcsolat olyan jellegü is lehet, amelynek mérésére egyik korrelációtípus sem alkalmas.

Előfordulhat, hogy két változó közötti szignifikáns kapcsolat egy harmadik változó hatása következtében mérhető, például időbeli trenddel vagy szezonalitással rendelkező adatsorok esetén, amely a következőképpen szemléltethető. Ha közepes földrajzi szélességeken két rácspont geopotenciális magasságának idősora korrelál egymással, annak hátterében nemcsak távkapcsolat, hanem az éves menetük is állhat. A Napból érkező sugárzás mennyiségének növekedéséből vagy csökkenéséből adódóan a geopotenciális magasság értékek is együtt változhatnak, azaz erősebb korreláció mérhető közöttük. Távkapcsolatok téves azonosításának elkerülése érdekében az adatsorokból kivontuk a lineáris trendet, a szezonalitás mértékét pedig napi anomália adatsorok képzésével csökkentettük, azaz kivontuk minden egyes napból az arra a napra vonatkozó, teljes - azaz harminc éves - időszakra jellemző átlagos értéket.

\section{Empirikus ortogonális sorfejtés}

A rácsponti idősorok több ezer dimenziós, korrelált mezőnek tekinthetők. Változékonyságuk vizsgálatára célszerü adatredukciós módszert, például empirikus ortogonális sorfejtést ( $\mathrm{pl}$. Joliffe, 2002) választanunk. A térbeli változékonyságot az $500 \mathrm{hPa}$-os geopotenciális magasságmezőböl képzett, egymásra meröleges, korrelálatlan empirikus ortogonális függvények ${ }^{10}$ képzésével elemezhetjük. Ezek olyan lineáris kombinációk, amelyekben minden változó - a térbeli változékonyság vizsgálata esetén rácspont - valamilyen súllyal kerül figyelembe vételre. Az EOF-ek súlyai térképen ábrázolhatók. Fontos megjegyeznünk, hogy a súlyok számértéke különbözö EOF-ek összehasonlítására nem alkalmas, továbbá összesen annyi EOF létezik, ahány változó. A lineáris kombinációk úgy állnak elő, hogy az első EOF fejezze ki a geopotenciális magasságmező változékonyságának legnagyobb hányadát. Az összes EOF figyelembevételével megkapjuk a mező teljes változékonyságát. A módszer azért tekinthető dimenzióredukciós eljárásnak, mert az első néhány EOF figyelembevételével a mező teljes változékonyságának meghatározó része leírható, vagyis a többi EOF elhagyható jelentős információveszteség nélkül.

A vizsgálat azonban rendkívül érzékeny a területválasztásra és - a korrelációanalízissel ellentétben - a rácsponti adatsorok súlyozására. A rácsponti adatsorokat ezért földrajzi szélesség szerint súlyoztuk. A vizsgálathoz az é.sz. $20^{\circ}$ és $90^{\circ}$ közötti, valamint ny.h. $80^{\circ}$ és k.h. $80^{\circ}$ közötti észak-atlanti/európai térséget választottuk, amelyben az Atlanti-óceán északkeleti medencéje feletti, illetve a Földközi-tenger térsége fölötti akciócentrumpár is megtalálható, ame-

\footnotetext{
${ }^{10}$ Empirical orthogonal function, EOF
} 
lyeket korábban (Kristóf et al., 2018a) már korrelációanalízissel azonosítottunk. Az első EOF az Észak-atlanti Oszcilláció dipólus szerkezetét jeleníti meg (pl. Hurrel \& Deser, 2010).

Ahhoz, hogy a megfigyelésekkel összevethető eredményt kapjunk a statisztikai vizsgálat végén, célszerü az EOF-analízist ún. varimax-rotációval végrehajtani. Ha a geopotenciális mező adatait háromdimenziós Descartes-koordinátarendszerben képzeljük el, amelynek tengelyei a földrajzi szélesség, a földrajzi hosszúság és az idő, akkor a varimax-rotáció az empirikus ortogonális függvényeket úgy forgatja, hogy az első függvény a mező legnagyobb szórásának ,irányába” essen. A módszer azonban érzékeny arra, hogy hány függvényt rotálunk. Példaképpen az egyik harmincéves időszak varimax-rotációval elvégzett EOF-analízisét tekintjük, amely során az első 3, 5, 15, 25, 100, majd az összes EOF, vagyis 2640 rotációjára került sor (1. ábra).
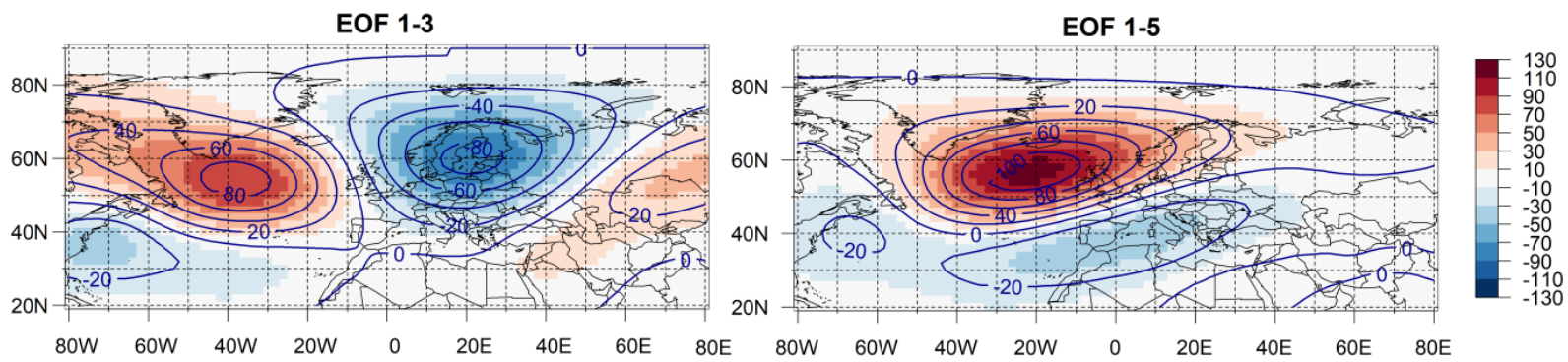

EOF 1-15
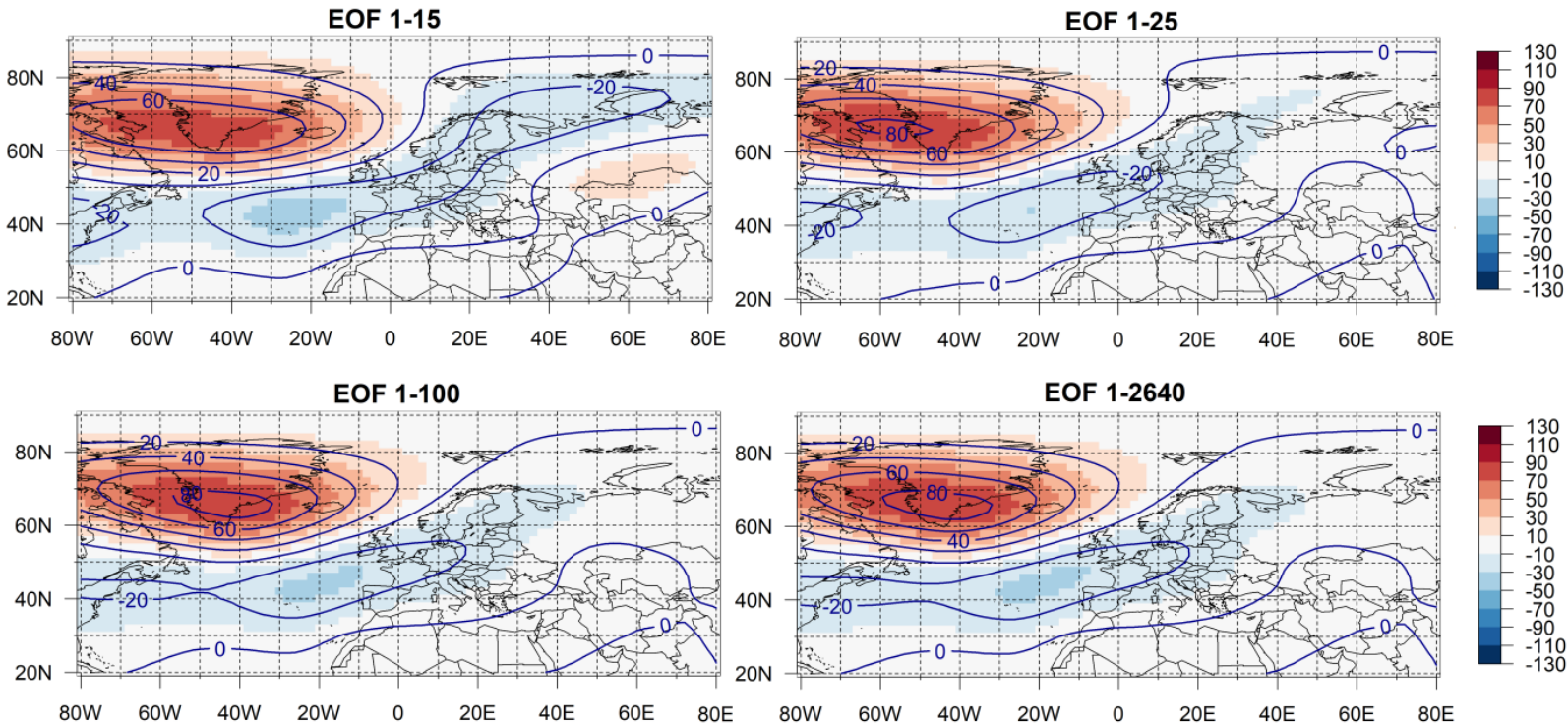

1. ábra: Az ERA-20C 1971-2000 közötti 500 hPa-os geopotenciális magasságmezőjén elvégzett EOF-analízis, varimax-rotációval. A térképeken az EOF-súlyokat ábrázoltuk.

Az észak-dél tengelyű dipólus szerkezet az első 15 EOF rotációját követően válik felismerhetővé. Az összes EOF rotációjával végzett EOF-analízis eredményeképpen kapott súlyok térbeli korrelációja a 3, 5, 15 és 25 EOF rotációjával végzett vizsgálat alapján kapott súlyokkal rendre $0,45,0,33,0,97$ és 0,98 . A 2640 darab empirikus ortogonális függvényböl az első 100 rotációja 0,99 fölötti korrelációt eredményez.

A korrelációanalízist és az empirikus ortogonális sorfejtést elvégeztük a GCM-ekre is. Egyezésüket az ERA-20C-vel az abszolút minimális korrelációk, valamint az EOF-súlyok eloszlása alapján értékeltük, a térbeli korrelációk, a szórások és átlagos négyzetes hiba négyzetgyökét jellemző centrált értékek ${ }^{11}$ kiszámításával (Taylor, 2001). A korrelációanalízis

\footnotetext{
${ }^{11}$ centered root-mean-square (RMSc) difference
} 
alapján a legpontosabb modellnek a HadGEM2-CC és az MPI-ESM-P modell bizonyult, azonban ezek térbeli korrelációja az ERA-20C-vel alig haladta meg a 0,8 értéket, így az RMSc érték is viszonylag magas maradt. Az empirikus ortogonális sorfejtés alapján magasabb korrelációk, kisebb szórások és RMSc értékek adódtak. Ennek során a legpontosabb modellnek a HadGEM2-CC mellett az MPI-ESM-LR modell bizonyult (Kristóf et al., 2018a, 2018b).

\section{Az észak-atlanti/európai térségben azonosított távkapcsolati rendszerek és a Kárpát- medence felszínközeli hőmérsékletének statisztikai kapcsolata}

Az azonosított távkapcsolati rendszerek intenzitásának mérésére különféle indexek képezhetők. Ennek legegyszerübb módja a szóban forgó jelenséget jellemző, mérőállomások idősoraiból képzett, ún. állomásalapú index korreláltatása a vizsgált térség légköri állapothatározóival. Adott oszcillációra vonatkozóan különböző indexeket határoztak meg, például a NAO-indexet Hurrell (1995) a portugáliai Lisszabon és az izlandi Reykjavík, míg Cropper et al. (2015) az azori-szigeteki Ponta Delgada és az izlandi Stykkishólmur, illetve Reyjkavík állomás tengerszinti légnyomásértékeinek különbségeként állított elő. Az MO-index pedig az algériai Algír és az egyiptomi Kairó, illetve a Nagy-Britanniához tartozó Gibraltár és az izraeli Tel-Aviv mérési adatsorainak különbségeként került elöállításra (Palutikof et al., 2003).

Szemléltetésképpen Cropper et al. (2015) napi NAO-index adatsora és a két MO-index adatsor, mint „hivatalos” index adatsorok statisztikai kapcsolatát vizsgáljuk a Kárpát-medence felszínközeli ( $2 \mathrm{~m}$-es) léghömérsékletével az é.sz. $44^{\circ}-50^{\circ}$ és k.h. $16^{\circ}-24^{\circ}$ területen, Pearsonkorrelációk számításával. Az ERA-20C különböző időszakokra vonatkozó reanalízis adatsoraira a korrelációk a 2. ábrán találhatók. Szignifikáns korrelációk, vagyis abszolút értékben 0,2-nél erősebb korrelációk a térség északi, északnyugati részén figyelhetők meg, a NAO pozitív fázisában. Ez a következőképpen értelmezhető. Az Atlanti-óceán északkeleti medencéje fölött, Izland környékén erősödő ciklonális, míg az Azori-szigetek fölött erősödő anticiklonális áramlás jellemző, így délnyugatias áramlás alakul ki közepes földrajzi szélességeken és enyhébb időjárás figyelhető meg Európa-szerte. Az MO kapcsolatban áll a NAO-val, pozitív fázisában a nyugati pólusa erősen fejlett, amely szintén az Azori-anticiklon erősödésének következménye. A három időszakot tekintve megállapítható, hogy a szignifikáns pozitív korrelációk kismértékben erősödtek az ezredfordulóhoz közeledve, míg a szignifikáns negatív korrelációk gyengültek. Az index adatsorok és a hőmérséklet Spearman-korrelációval való vizsgálata alapján a korrelációk hasonló eloszlását kaptuk (ezt itt nem mutatjuk be).

Míg az ERA-20C esetében mérhetők szignifikáns korrelációk, a GCM-ek Kárpát-medencére vonatkozó felszínközeli léghömérsékleti adatsorai és a fentebb említett NAO- és MOindexek között csak gyenge, 0,1 körüli vagy az alatti korrelációk adódtak.

Indexek az 500 hPa-os geopotenciális magasságmező alapján is létrehozhatók, például az elöbb felsorolt állomásokhoz legközelebb eső rácspontok idősorainak különbségét képezve. Az ERA-20C esetén a hivatalos indexekkel számolt értékekhez hasonló korreláció eloszlás kapható. A GCM-ek esetén is mérhető szignifikáns, abszolút értékben 0,4 erősségü korreláció, azonban általánosan a NAO és a hőmérséklet pozitív korrelációja az északnyugati területeken kevéssé figyelhető meg, míg az MO és a hőmérséklet kapcsolatában túlbecsülik a szignifikáns negatív korrelációkat (terjedelmi korlátok miatt itt ezt nem illusztráljuk).

Indexképzés alapjaként azon rácspontpárok adatsorait is választhatjuk, amelyeket akciócentrumokként jelöltünk ki az abszolút minimális korrelációk vizsgálata során, így az ERA20C esetében a 2. táblázatban közölt földrajzi koordinátájú rácspontpárok adatsorait. Bár vannak olyan GCM-ek, amelyek esetében az abszolút minimális korrelációk eloszlása jelentős 
hasonlóságot mutat az ERA-20C-vel - korrelációjuk 0,8 fölötti - az akciócentrumokként megjelölt rácspontpárok földrajzi helyzete modellenként jelentős eltérést mutat, különösen a NAO esetén. A GCM-ek többsége az ERA-20C-hez képest nyugatabbra pozícionálja az Atlanti-óceán északkeleti medencéje felett található akciócentrumpárt, ezért szignifikáns korrelációk nem mérhetők az akciócentrumpárt jellemző index és a Kárpát-medence felszínközeli hőmérséklete között.
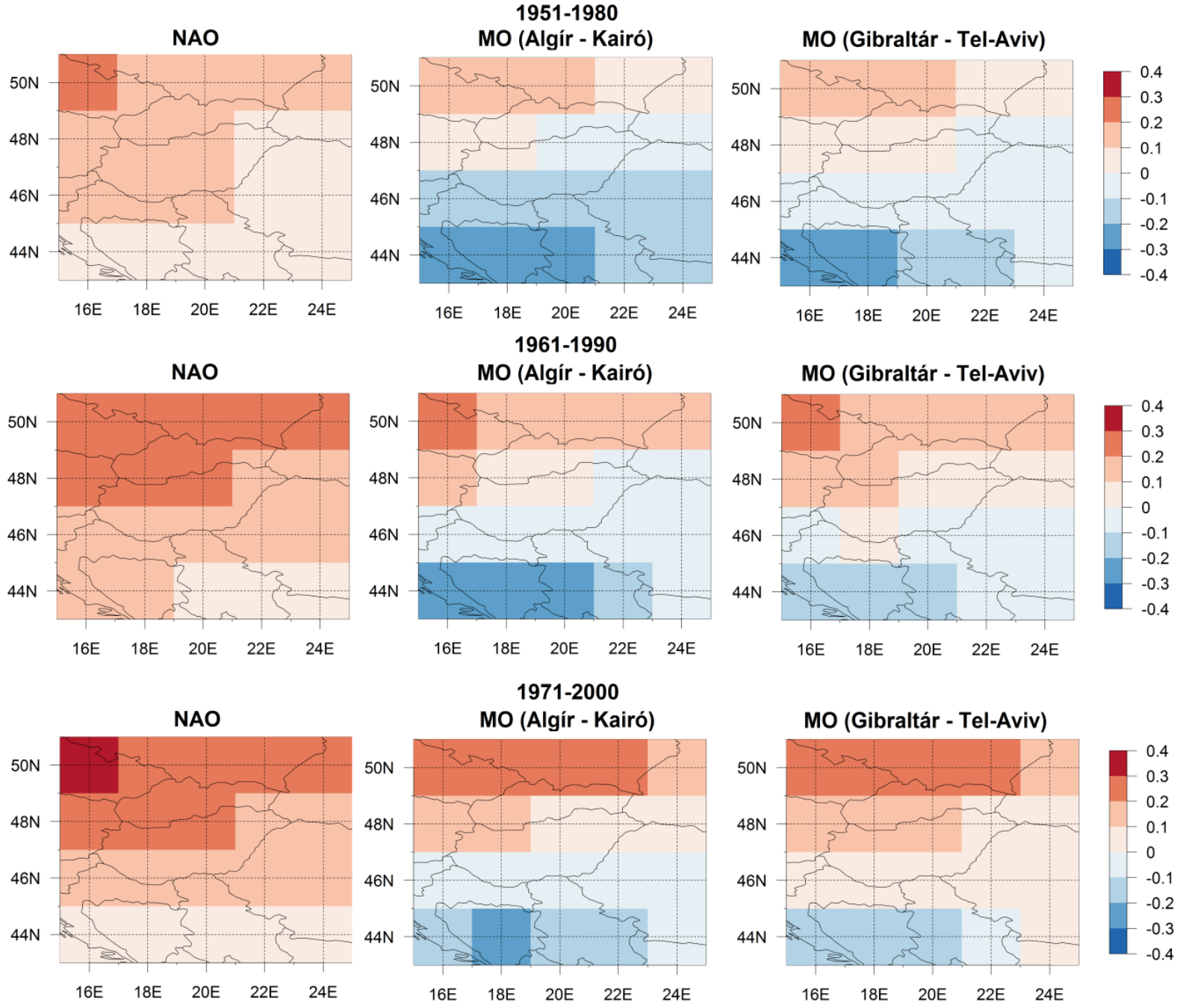

2. ábra: A NAO- és az MO-indexek Pearson-korrelációja a Kárpát-medence felszínközeli léghőmérsékletével, az ERA-20C adatbázis alapján, 1951-1980, 1961-1990 és 1971-2000 időszakra.

\section{Összefoglalás}

A távkapcsolati rendszerek azonosítására a korrelációanalízis és az empirikus ortogonális sorfejtés alkalmas módszernek bizonyult az ERA-20C és a GCM-ek historikus $500 \mathrm{hPa}$-os geopotenciális magasság adatainak elemzése során. A Kárpát-medencére gyakorolt hatásuk vizsgálata érdekében az oszcillációkat minél jobban kifejező index adatsorok konstruálandók, amely például a geopotenciális magasságmező időbeli változékonyságának vizsgálata útján is történhet, fökomponens-elemzéssel. További célunk a statisztikai kapcsolatok minél alapo- 
sabb felderítését követően a legpontosabbnak bizonyuló GCM-ek jövőre vonatkozó szimulációinak részletes vizsgálata.

\section{Köszönetnyilvánítás}

Kutatásainkat támogatta az Agrárklíma2 projekt (VKSZ_12-1-2013-0034), a Nemzeti Kutatási, Fejlesztési és Innovációs Alap K-120605 és K-129162 számú projektje, a Széchenyi 2020 program, Magyarország Kormánya és az Európai Regionális Fejlesztési Alap az AgroMo kutatási projekt (GINOP-2.3.2-15-2016-00028) keretében, valamint az Emberi Eröforrások Minisztériuma az ELTE Felsőoktatási Intézményi Kiválósági Program (1783-3/2018/ FEKUTSRAT) keretében.

\section{Hivatkozások}

Barnston, A.G., Livezey, R.E., 1987: Classification, Seasonality and Persistence of LowFrequency Atmospheric Circulation Patterns. Mon. Weather Rev., 115: 1083-1126. https://doi.org/10.1175/1520-0493(1987)115<1083:CSAPOL $>2.0 . C O ; 2$

Bi, D., Dix, M., Marsland, S.J., O'Farrell, S., Rashid, H.A., Uotila, P., Hirst, A.C., Golebiewski, E.K.M., Sullivan, A., Yan, H., Hannah, N., Franklin, C., Sun, Z., Vohralik, P., Watterson, I., Zhou, Z., Fiedler, R., Collier, M., Ma, Y., Noonan, J., Stevens, L., Uhe, P., Zhu, H., Griffies, S.M., Hill, R., Harris, C., Puri, K., 2013: The ACCESS coupled model: description, control climate and evaluation. Australian Meteorological and Oceanographic Journal, 63: 41-64. https://doi.org/10.22499/2.6301.004

Climate Data Operators version 1.7.2 (Available at http://mpimet.mpg.de/cdo.)

Conte, M., Giuffrida, A., Tedesco, S., 1989: The Mediterranean Oscillation: impact on precipitation and hydrology in Italy. Conference on Climate and Water, Publications of the Academy of Finland, Helsinki, 1, 121-137.

Cropper, T., Hanna, E., Valente, M.A., Jónsson, T., 2015: A daily Azores-Iceland North Atlantic Oscillation index back to 1850. Geoscience Data Journal, 2: 12-24. https://doi.org/10.1002/gdj3.23

A NAO-index adatsor elérhetősége: https://zenodo.org/record/9979\#.W18IstIzY2w.

European Centre for Medium-Range Weather Forecasts (2014, updated daily): ERA-20C Project (ECMWF Atmospheric Reanalysis of the 20th Century). Research Data Archive at the National Center for Atmospheric Research, Computational and Information Systems Laboratory. https://doi.org/10.5065/D6VQ30QG (Letöltés utolsó időpontja: 2017. dec. 7.)

Gent, P.R., Danabasoglu G., Donner, L.J., Holland, M.M., Hunke, E.C., Jayne, S.R., Lawrence, D.M., Neale, R.B., Rasch, P.J., Vertenstein, M., Worley, P.H., Yang, Z.L., Zhang, M., 2011: The Community Climate System Model version 4. J. Clim., 24: 4973-4991. https://doi.org/10.1175/2011JCLI4083.1

Hurrell, J.W., 1995: Decadal trends in the North Atlantic Oscillation, regional temperatures and precipitation. Science, 269: 676-679. https://doi.org/10.1126/science.269.5224.676

Hurrell, J.W., Deser, C., 2010: North Atlantic climate variability: The role of the North Atlantic Oscillation. Journal of Marine Systems, 79: 231-244.

https://doi.org/10.1016/j.jmarsys.2008.11.026

Joliffe, I.T., 2002: Principal Component Analysis. 2nd Edition. Springer-Verlag, New York.

Jung, T., Hilmer, M., 2000: Evidence for a recent change in the link between the North Atlantic Oscillation and Arctic Sea ice export. Geophys. Res. Lett., 27: 989-992. https://doi.org/10.1029/1999GL010944 
Kristóf, E., Bartholy, J., Pongrácz, R., 2018a: Statistical relationships between large-scale oscillation phenomena and meso-scale atmospheric conditions over Central/Eastern Europe and their representation in CMIP5 General Circulation Models. In: 98th Annual Meeting of the American Meteorological Society. Austin (TX), 2018.01.07-2018.01.20. American Meteorological Society, Paper 331148, 9p. https://ams.confex.com/ams/98Annual/ webprogram/Manuscript/Paper331148/KE-PR-BJ-AMS2018.pdf

Kristóf, E., Bartholy, J., Pongrácz, R., 2018b: Az 500 hPa-os geopotenciális magasságmező változékonyságának vizsgálata az észak-atlanti/európai térségben reanalízis adatbázis és globális klímamodellek szimulációi alapján. In: XVII. Természet-, Müszaki- és Gazdaságtudományok Alkalmazása Nemzetközi Konferencia. Szombathely, 2018.05.12. $8 \mathrm{p}$.

Livezey, R.E., Chen, W.Y., 1983: Statistical Field Significance and its Determination by Monte Carlo Techniques. Mon. Weather Rev., 111: 46-59. https://doi.org/10.1175/15200493(1983) $111<0046:$ SFSAID $>2.0$. CO;2

$\mathrm{R}$ Core Team, 2016: R: A language and environment for statistical computing. R Foundation for Statistical Computing, Vienna, Austria. (Available at https://www.R-project.org/.)

Palutikof, J.P., 2003: Analysis of Mediterranean climate data: measured and modelled. In: Mediterranean climate: Variability and trends. (Bolle, H.J., ed.) Springer-Verlag, Berlin. Az MO-index elérhetősége: https://crudata.uea.ac.uk/cru/data/moi/. https://doi.org/10.1007/978-3-642-55657-9_6

Scoccimarro, E., Gualdi, S., Bellucci, A., Sanna, A., Fogli, P.G., Manzini, E., Vichi, M., Oddo, P., Navarra, A., 2011: Effects of Tropical Cyclones on Ocean Heat Transport in a High Resolution Coupled General Circulation Model. J. Clim., 24: 4368-4384. https://doi.org/10.1175/2011JCLI4104.1

Stevens, B., Giorgetta, M., Esch, M., Mauritsen, T., Crueger, T., Rast, S., Salzmann, M., Schmidt, H., Bader, J., Block, K., Brokopf, R., Fast, I., Kinne, S., Kornblueh, L., Lohmann, U., Pincus, R., Reichler, T., Roeckner, E., 2013: The Atmospheric Component of the MPIM Earth System Model: ECHAM6. Journal of Advances in Modeling Earth Systems, 5: 146-172. https://doi.org/10.1002/jame.20015

Taylor, K., Stouffer, R.J., Meehl, G.A., 2012: An overview of CMIP5 and the experiment design, Bull. Am. Meteorol. Soc., 93: 485-498. https://doi.org/10.1175/BAMS-D-1100094.1

Taylor, K.E., 2001: Summarizing multiple aspects of model performance in a single diagram. J. Geophys. Res., 106: 7183-7192. https://doi.org/10.1029/2000JD900719

The HadGEM2 Development Team: Martin, G.M., Bellouin, N., Collins, W.J., Culverwell, I.D., Halloran, P.R., Hardiman, S.C., Hinton, T.J., Jones, C.D., McDonald, R.E., McLaren, A.J., O'Connor, F.M., Roberts, M.J., Rodriguez, J.M., Woodward, S., Best, M.J., Brooks, M.E., Brown, A.R., Butchart, N., Dearden, C., Derbyshire, S.H., Dharssi, I., DoutriauxBoucher, M., Edwards, J.M., Falloon, P.D., Gedney, N., Gray, L.J., Hewitt, H.T., Hobson, M., Huddleston, M.R., Hughes, J., Ineson, S., Ingram, W.J., James, P.M., Johns, T.C., Johnson, C.E., Jones, A., Jones, C.P., Joshi, M.M., Keen, A.B., Liddicoat, S., Lock, A.P., Maidens, A.V., Manners, J.C., Milton, S.F., Rae, J.G.L., Ridley, J.K., Sellar, A., Senior, C.A., Totterdell, I.J., Verhoef, A., Vidale, P.L., Wiltshire, A., 2011: The HadGEM2 family of Met Office Unified Model climate configurations. Geosci. Model Dev., 4: 723-757. https://doi.org/10.5194/gmd-4-723-2011

Walker, G.T., Bliss, E.W., 1932: World Weather V. Memoirs of the Royal Meteorological Society, 4: 53-84. 
Watanabe, M., Suzuki, T., O’ishi, R., Komuro, Y., Watanabe, S., Emori, S., Takemura, T., Chikira, M., Ogura, T., Sekiguchi, M., Takata, K., Yamazaki, D., Yokohata, T., Nozawa, T., Hasumi, H., Tatebe, h., Kimoto, M., 2010: Improved climate simulation by MIROC5: Mean states, variability, and climate sensitivity. J. Clim., 23: 6312-6335. https://doi.org/10.1175/2010JCLI3679.1

Yukimoto, S., Yoshimura, H., Hosaka, M., Sakami, T., Tsujino, H., Hirabara, M., Tanaka, T.Y., Deushi, M., Obata, A., Nakano, H., Adachi, Y., Shindo, E., Yabu, S., Ose, T., Kitoh, A., 2011: Meteorological Research Institute-Earth System Model Version 1 (MRI-ESM1) Model Description. Technical Report of the Meteorological Research Institute, 64: 83. https://doi.org/10.11483/mritechrepo.64

\section{ORCID}

Kristóf E. (i) https://orcid.org/0000-0001-9892-9552

Bartholy J. (i) https://orcid.org/0000-0002-3911-7981

Pongrácz R. (D) https://orcid.org/0000-0001-7591-7989 